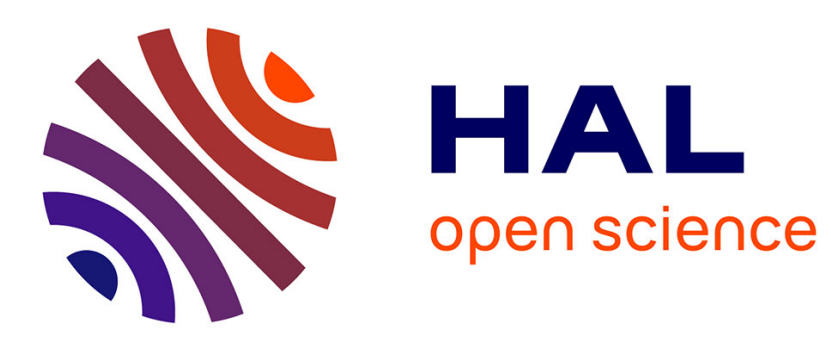

\title{
A Changeable Jig-Less Welding Cell for Subassembly of Construction Machinery
}

Mads Bejlegaard, Thomas Ditlev Brunoe, Kjeld Nielsen

\section{To cite this version:}

Mads Bejlegaard, Thomas Ditlev Brunoe, Kjeld Nielsen. A Changeable Jig-Less Welding Cell for Subassembly of Construction Machinery. IFIP International Conference on Advances in Production Management Systems (APMS), Aug 2018, Seoul, South Korea. pp.305-311, 10.1007/978-3-319-997049_37. hal-02164915

\section{HAL Id: hal-02164915 \\ https://hal.inria.fr/hal-02164915}

Submitted on 25 Jun 2019

HAL is a multi-disciplinary open access archive for the deposit and dissemination of scientific research documents, whether they are published or not. The documents may come from teaching and research institutions in France or abroad, or from public or private research centers.
L'archive ouverte pluridisciplinaire HAL, est destinée au dépôt et à la diffusion de documents scientifiques de niveau recherche, publiés ou non, émanant des établissements d'enseignement et de recherche français ou étrangers, des laboratoires publics ou privés. 


\title{
A Changeable Jig-less Welding Cell for Subassembly of Construction Machinery
}

\author{
Mads Bejlegaard ${ }^{10000-0002-8916-3601]}$, Thomas Ditlev Brunoe ${ }^{21111-2222-3333-4444]}$, Kjeld \\ Nielsen $^{3[1111-2222-3333-4444]}$ \\ ${ }^{1}$ Aalborg University, Fibigerstraede 16, 9220 Aalborg Oest, Denmark \\ bej legaardemp.aau.dk \\ ${ }^{2}$ Aalborg University, Fibigerstraede 16, 9220 Aalborg Oest, Denmark \\ tdp@mp.aau.dk \\ ${ }^{3}$ Aalborg University, Fibigerstraede 16, 9220 Aalborg Oest, Denmark \\ kni@mp.aau.dk
}

\begin{abstract}
The cost and technological development of industrial robots suggests a substitution of labor-intensive processes. Jig-less welding is an example of an emerging concept that is derived from this development, providing high flexibility without compensating on efficiency. This paper presents a conceptual solution of a jig-less welding cell for a particular environment with the purpose of investigating potential, expected challenges to overcome before implementation. To investigate the expected, potential challenges the concept is applied to a case study that takes its outset in a low volume, high variety welding facility. A fullscale test on the setup have yet to be conducted.
\end{abstract}

Keywords: Robot welding, jig-less welding, fixture-les welding, jigs, fixtures, changeability, flexibility, Industry 4.0 conformant welding

\section{Introduction}

The fourth industrial revolution has arrived, promising new levels of responsiveness, flexibility, and productivity [8], enabled through various new and emerging technologies. This manufacturing paradigm will turn companies into a source of higher value jobs [3], [10] and individualized production will be a competitive factor among others [3], [6]. Thus, by exploiting the global market trends of volatile demands through new technologies the fourth industrial revolution is expected to create competitive advantages for high-wage countries. However, companies must determine areas where new technology will expectedly contribute to increased competitiveness based on their specific company characteristics, and figure out how they can benefit from these new technological opportunities.

The capability of using the manufacturing systems across existing product variety and reusing it for future product generations is critical because of the importance of time-to-market and because products lifecycles are getting shorter [14]. Though the lifetime of manufacturing system components such as robots and conveying systems are already longer than that of products, it is relevant to further extend the lifetime of 
manufacturing systems and strive for manufacturing systems that enable individualized production. However, investments in changeability must be economically feasible for which reason changeability becomes a trade-off between the amount of variety a system can handle and the efficiency with which this variety is manufactured. This returns to the fact that the ability to balance economies of scale and economies of scope has become a major competitive factor [3], [4].

\subsection{Changeability}

In recent years, changeable manufacturing concepts as FMS (Flexible Manufacturing System) and RMS (Reconfigurable Manufacturing System) have been proposed in order for manufacturers to deal with product variety and volatile markets. Changeability is an umbrella term encompassing different types and degrees of changeability [4] considering both logical and physical changes on different factory structuring levels [16], which also applies to FMS and RMS. The FMS has often been criticized for covering disadvantages such as excess functionality, over-capacity, and the large initial investment. Conversely, RMS is promoted for its ability to continuously adapt to the exact functionality and capacity needed while performing an efficiency similar to that of the dedicated manufacturing line. However, this proves only successful across the variety represented within a product or part family because these capabilities are achieved by adding, removing, or exchanging modular elements of a system structure designed for a particular product or part family.

This paper addresses lower system levels (i.e. lower factory structuring levels), which implies that changeability is achieved through flexibility and reconfigurability. Changeability can be achieved in various ways depending on the object of change, and both flexibility and reconfigurability can be regarded as types of changeability. Builtin and pre-planned ability to change without physically altering the system structure is considered as flexibility whereas the ability to change the system structure to provide the exact capacity and functionality needed when needed is considered as reconfigurability [9], [15]. It can be difficult to choose the right changeability level for manufacturing systems since these decisions affects productivity and investment cost. This dilemma has become of great relevance to the case company subject to this paper.

\section{$1.2 \quad$ Jig-less welding}

In practice, manufacturing systems will most often require both flexibility and reconfigurability to meet a specific demand for a certain type of changeability. To address this, Andersen et al. [1] presented a model to evaluate different types of changeability best suited for a specific situation. For some welding tasks, Jig-less welding seem to offer both high flexibility together whit high productivity. The incentive for jig-less and fixture-less installation lies in time reduction related to changeovers and the cost reduction related to design, manufacturing, and installation of jigs and fixtures. These costs account for a great share of the total manufacturing cost.

Both jigs and fixtures are used for positioning and orientation of work-pieces in the welding process and both jigs and fixtures are costly auxiliary equipment. Therefore, 
this paper does not distinguish between jigs and fixtures but rather seeks to identify one alternative applicable to both of them. A literature search in Thomson Reuters Web of Science was carried out followed by a snowball approach to derive relevant literature from the literature first identified. To supplement the literature search a state of practice investigation was conducted to identify the prevalence of jig-less welding in industry. Five similar, global companies were visited.

At least for the last two and a half decade, jig-less and fixture-less assembly has been discussed [12]. Yet, in a review of challenges and outlook for the automotive assembly technologies from 2010 [11], flexible and adaptable assembly technology and strategy, e.g. robotic fixture-less assembly in the assembly process, was mentioned as one of more initiatives that the automotive industry will have to pursue to respond successfully to market demand. Likewise, trends in manufacturing and assembly for next generation of combat aircraft has been presented in 2014 [2], introducing a new concept for jigless assembly. A number of flexible grippers to enable jig-less assembly in high volume automotive industry have also been developed [13], [17]. Additionally, another publication emphasizes the development of jig-less laser welding in the car industry [7]. However, low volume industry can potentially gain enormous benefits from jig-less assembly as well. This potential does not seem as distant as previously since the technological development (e.g. various sensors) have provided robots with greater flexibility [5]. Even though this development is not reflected in literature, the state of practice reveals that e.g. the company Yaskawa has released a number of jig-less applications, not only in the automotive industry, but also in Small and Medium Enterprises (SMEs), for instance within the agricultural industry and the construction machine industry, though with relative high repetition.

The concept of jig-less welding challenges the traditional understanding of increased flexibility having a negative effect on productivity. It seems that the technology has come to a level to which it is worth considering if it can be implemented as a new assembly technology for welding large and heavy, high variety, low volume steel components. This leads to the research question of this paper: What are the potential challenges of implementing jig-less welding in industries where large and heavy steel plates are being welded together.

To address this research question, a case study is performed. The case is a Danish SME that manufactures large and heavy body parts for construction machinery.

\section{Case study}

The product components in this case study consist of large steel plates and can have a weight of up to 2 tons after they have been welded together. In this category, there are approximately 80 different product components, of which some come in a few variants. The case company has long had an ambition to get a one-piece flow, in order to reduce stock and reduce the manufacturing lead time. However, with the current manufacturing setup this has proven impractical due to long changeover times.

Process \#1: Tack welding (manual) $\quad$ Process \#2: Full welding (robot) 


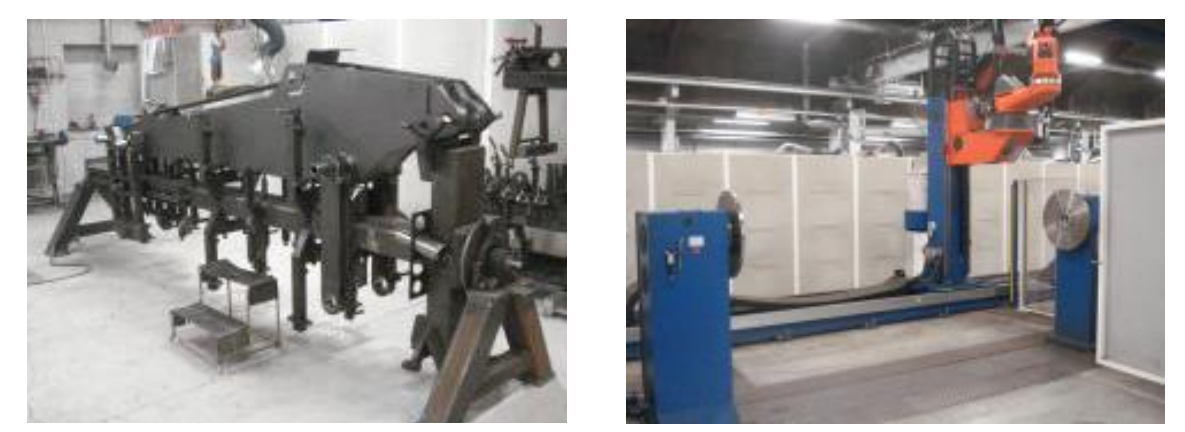

Fig. 1. The existing, conventional welding process sequence

Tack welding of large steel plates requires large and heavy fixtures and a change from one variant to another requires change of fixture. Therefore, the case company experiences many time consuming changeovers across the high variety of product components, as there is typically one unique fixture per product component in both processes illustrated in Fig. 1. A changeover can account for as much as $20 \%$ of the actual process time of the tack welding process. However, the major cost driver related to auxiliary equipment (e.g. jigs and fixture) is the New Product Introduction (NPI) cost related to design, manufacturing, and installation, and the following cost of storing and maintaining such equipment.

The issue described above can to some extent be addressed by the traditional approach of balancing stock levels and productivity. Another way to counter these issues could be to increase the changeability in auxiliary equipment (e.g. fixtures and jigs) by substituting the existing equipment by standard modular equipment, reconfigurable equipment, or flexible equipment. All three of them have advantages. Another solution, which is the focus of this paper, is based on a total elimination of auxiliary equipment.

In a collaboration between Aalborg University, the case company, and the Danish Technological Institute, the concept of a new jig-less welding cell has been created. The welding cell is shown in Fig. 2. The collaboration between the three stakeholders has helped to uncover challenges as well as economic benefits that follow the implementation of jig-less welding in this particular application. This helped the case company to decide if they should look further in to jig-less welding as an alternative to the traditional approach. The challenges identified during the project are as follows:

- Traditionally, there have not been the same requirements to tolerances as those that are needed for jig-less welding. Generally, there is a need for more reliable mastering of the supplying processes and the focal process to ensure continuous, trouble-free operations. The manually performed processes possess the capabilities to compensate for fluctuating tolerances why reliable mastering of supplying processes is less urgent compared to the fully automated jig-less welding process. 


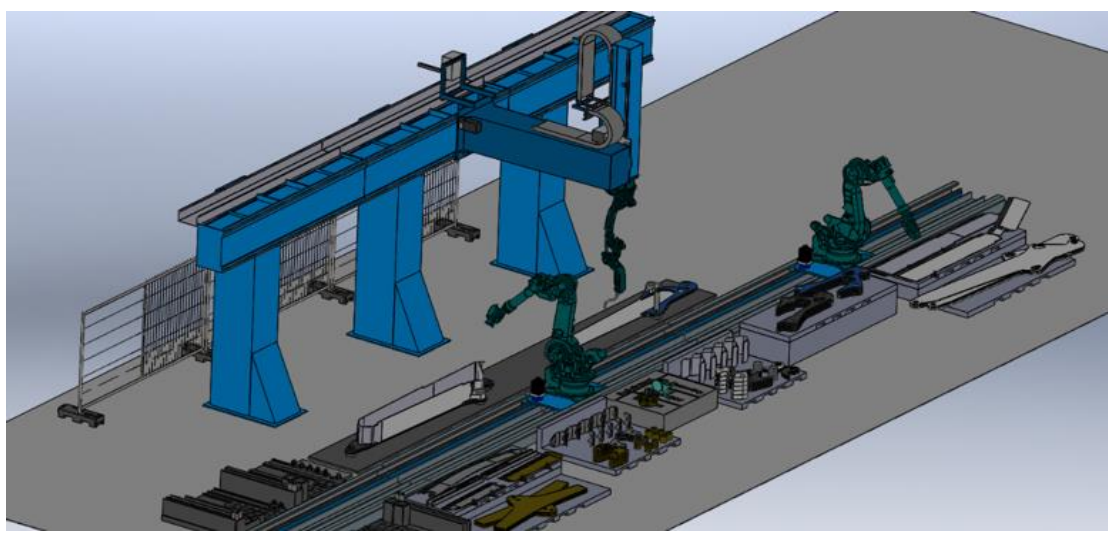

Fig. 2. Jig-less welding cell for both tack welding and full welding

- There will be a competence shift, both for operating the system but also for introducing new product component variants. On the shop floor robots substitute manually performed jobs. The design, manufacturing, and installation of auxiliary equipment (e.g. fixtures) are no longer necessary. However, NPIs will require new robot programs.

- High variety, low volume environments involves high complexity, which makes the cooperation and coordination of the robots essential. Thus, the control unit must be able to coordinate and synchronize robots to ensure perfect path behavior and high precision.

- Adopting jig-less welding to a high variety, low volume environment implies more frequent introduction of new product components compared to situations with less variety and higher volume. Thus, the time spent on NPIs due to time-consuming programming of robots can be quite considerably in low volume, high variety environments.

- An implementation would benefit from a standardization of the product components. This is however not unique for this particular application. A standardization of the product will not only have positive influence on the needed hardware flexibility but also the ability to reuse pieces of welding programs.

- The investment in jig-less welding is quite capital intensive. However, from a lifetime perspective changeable systems as the jig-less welding cell will have a tendency to be reasonable investment over time, since the investment cost can be spread over more product generations compared to traditional systems with a more rigid structure. By eliminating the changeover time and decreasing the process time, it is likely to face excess capacity, which should be considered when dimensioning the system.

- Too high heat input will have a great impact on product component distortion. This leads to two challenges; robots will have to compensate for distortion and the lowest possible heat input should be found. Jig-less welding in this particular application implies some technological uncertainties and no reference applications exist to our knowledge, and therefore the project is subject to some degree of uncertainty. 
Nevertheless, the proposed design of a jig-less welding cell is suggested to replace both the manual tack welding process, where ingoing parts are put together and the following welding process, where all welds are being fully welded in a welding robot. The latter process is planned phased out. Thereby, the two previous applied processes will be incorporated in one process and the jigs and fixtures becomes redundant. This novel concept will help the case company to reduce the changeover time. Additionally, the NPI cost of design, manufacturing, and installation of new manufacturing equipment is no longer existing but instead there will be a NPI cost related to programming of the new system when a new product component is introduced. Soft changes as programming is in this case less expensive than the hard changes of equipment currently seen.

\section{Conclusion}

The cost and technological development of industrial robots might suggest that robots should replace labor-intensive processes. This has led to the emergence of jig-less welding. Jig-less welding opens for automation of processes without giving up on either efficiency or flexibility. A number of industrial visits and a literature review did not uncover any alternative novel solution that suggests a substitution of jigs and fixture in the welding process in this particular industry. This paper investigates the potential challenges of implementing jig-less welding in industries assembling large and heavy steel plates. Despite the fact that jig-less welding will eliminate the cost related to design, manufacturing, installation, and storage of auxiliary equipment (e.g. jigs and fixtures) jig-less welding represents some challenges, which must be overcome before fully automatic jig-less welding can be implemented in the concerned industry.

\section{References}

1. Andersen, A., Brunø, T. D., Nielsen, K. et al.: Evaluating the Investment Feasibility and Industrial Implementation of Changeable and Reconfigurable Manufacturing Systems. Flexible services and manufacturing journal, (2017 (in review))

2. Balaji, H., Selvaraj, P., Rao, V. S.: Trends in Manufacturing and Assembly Technologies for Next Generation Combat Aircraft. ARPN Journal of Engineering and Applied Sciences 5, 667-673 (2014)

3. Brecher, C., Jeschke, S., Schuh, G. et al.: Integrative production technology for high-wage countries. In: Anonymous . Springer (2012)

4. ElMaraghy, H. A., \& Wiendahl, H. P.: Changeability - An Introduction. In: ElMaraghy, H.A. (ed.) Changeable and Reconfigurable Manufacturing Systems, pp. 3-24. Springer London (2009)

5. Ha, J.: An Image Processing Algorithm for the Automatic Manipulation of Tie Rod. International Journal of Control, Automation and Systems 11, 984-990 (2013)

6. Jeschke, S., Brecher, C., Meisen, T. et al.: Industrial Internet of Things and Cyber Manufacturing Systems. In: Jeschke, S., Brecher, C., Song, H., et al (eds.) Industrial Internet of Things, pp. 3-19. Springer (2017) 
7. Kampker, A., Bergweiler, G., Hansen, J. O. et al.: Jigless Laser Welding in the Car Body Production. ATZ worldwide 119, 72-75 (2017)

8. Koren, Y.: The global manufacturing revolution: Product-process-business integration and reconfigurable systems. John Wiley \& Sons (2010)

9. Koren, Y., \& Shpitalni, M.: Design of Reconfigurable Manufacturing Systems. Journal of Manufacturing Systems 29, 130-141 (2010)

10. McKinsey, G. I.: Manufacturing the Future: The Next Era of Global Growth and Innovation. McKinsey Global Institute, (2012)

11. Michalos, G., Makris, S., Papakostas, N. et al.: Automotive Assembly Technologies Review: Challenges and Outlook for a Flexible and Adaptive Approach. CIRP Journal of Manufacturing Science and Technology 2, 81-91 (2010)

12. Mills, J.: Multi-Manipulator Control for Fixtureless Assembly of Elastically Deformable Parts. 1565-1572 (1992)

13. Paquin1a, V., \& Akhloufi2b, M.: Vision-Guided Universal Articulated Gripper for Jigless Robot Welding. 68 (2012)

14. Roland Berger Strategy Consultants GmbH: Mastering product complexity. In: Anonymous . Roland Berger Strategy Consultants GmbH, Online (2012)

15. Terkaj, W., Tolio, T., Valente, A.: Focused flexibility in production systems. In: ElMaraghy, H.A. (ed.) Changeable and Reconfigurable Manufacturing Systems, pp. 47-66. Springer (2009)

16. Wiendahl, H., ElMaraghy, H. A., Nyhuis, P. et al.: Changeable Manufacturing-Classification, Design and Operation. CIRP Annals-Manufacturing Technology 56, 783-809 (2007)

17. Yeung, B. H., \& Mills, J. K.: Design of a Six DOF Reconfigurable Gripper for Flexible Fixtureless Assembly. IEEE Transactions on Systems, Man, and Cybernetics, Part C (Applications and Reviews) 34, 226-235 (2004) 